DOI https://doi.org/10.18551/rjoas.2017-09.33

\title{
ASSESSMENT OF SEVERAL AMPHIBIAN RICE VARIETIES IN THE CENTER OF RICE PRODUCTION IN LAMONGAN REGENCY OF EAST JAVA PROVINCE
}

\author{
Sudaryono Tri, Researcher \\ Assessment Institute for Agricultural Technology, Malang, Indonesia \\ Email: tri sdr@yahoo.com
}

\begin{abstract}
Climate change due to global warming has brought wide impact on various aspects of life; one of the most serious impacts is in agriculture sector. One of the ways to overcome the situation is to provide several varieties of amphibian rice to be planted in less-water condition. To accelerate the spread of amphibian varieties to users, an assessment was carried out by applying Integrated Approach to Crop . The purpose of this assessment was to determine the growth and production performance of several amphibian rice varieties, so the VUB can substitute and anticipate drought to overcome crop failure in long dry season (elnino phenomenon). The assessment was conducted in Maduran Village, Maduran District, Lamongan Regency from August to November 2015. The study used Inpago 5, Inpago 8, Inpago 9, Inpari 10, Situ Patenggang, and Ciherang varieties as comparison with total area of 10 ha. The study was done using Randomized Block Design with four (4) replications. The parameters observed included growth component, pest attack, and production. The results showed that the treatment on amphibian varieties had significant effect on plant height and number of tillers. Of the 5 (five) amphibian varieties studied, Inpago 9 production was higher (8.31 $\mathrm{t} / \mathrm{ha}$ ) than the other four varieties.
\end{abstract}

\section{KEY WORDS}

Amphibian rice variety, integrated approach to crop, wetland rice.

The government is targeting rice self-sufficiency and sustainable rice self-sufficiency with a production target of 73.40 million tons by 2015 . East Java as the main producer of rice contributes to national rice production $\pm 20 \%$ is generated from \pm 1.62 million ha/year with average productivity of $53 \mathrm{qu} / \mathrm{ha}$. The target achievement scenario is mostly pursued through productivity improvement of 63.23 qu/ha [1]. In 2013, rice production reached 12,049,342 tons, with the contribution of East Java Province to national rice production as much as $16.90 \%$ [2]. It is expected that by 2015 the rice production target will reach 12.86 million tons [3].

Climate change due to global warming has brought wide impact on various aspects of life. Agriculture is the most seriously affected sector. Changes in rainfall patterns, increased extreme climatic events, and rising temperatures and sea levels have led agricultural production, especially the food crop sub-sector, to decline significantly. It is estimated that agricultural productivity will continue to decline in line with global temperature rise.

In the midst of the world food crisis triggered by climate change, the government still targets to increase the productivity of food crops, especially rice. To achieve the target, integrated and comprehensive work is required as well as coordination among all stakeholders, both at the central and regional levels, in policy, programming, and technology implementation, especially in the anticipation and mitigation of climate change threats. To that end, the Ministry of Agriculture has developed the Climate Change Research and Development Consortium.

The role of technology in improving agricultural production and the welfare of farmers has been widely recognized. In the past 25 years, the Body for Agricultural Research and Development has been instrumental in agricultural development through the creation of superior varieties technology, efficient cultivation system, pest and disease control, harvest and post-harvest technology, and the use of agricultural tools and machinery. In order to 
increase the productivity and efficiency of food crop, an Integrated Approach to Crop and resource management has been developed [4].

In principle, the increase in rice production and productivity is still possible since there is a gap between potential yields and actual yields. This is because of (i) the use of high yield seed varieties is low, only around $53 \%$, (ii) unbalanced and inefficient use of fertilizers, (iii) the unpopular use of organic fertilizers, and (iv) location-specific cultivation has not yet been developed. Through the program established by the Ministry of Agriculture, East Java Province strives to encourage and accelerate the increase of food production by implementing technological innovation, IP enhancement, and integrated site-specific resource management in order to achieve the established production target.

Adaptation to climate change is an urgent priority for Indonesia. All ministries and national planning need to consider climate change in their programs regarding issues such as poverty reduction, community empowerment, food security, disaster management, disease control, and urban planning. However, this is not a mere central government task; it should be a national effort involving local governments, the general public, and all nongovernmental organizations, as well as UNDP private parties [5].

Technology of Agricultural Research Agency in anticipation of drought for rice commodity is available. However, hardening in the form of assessment, facilitation, and socialization of the resulting technology needs to be disseminated in drought-prone locations in the form of assessment of varieties to recommend the use of site-specific superior varieties.

The purpose of the assessment is to determine the growth and production performance of some amphibian rice varieties, so VUB can substitute and anticipate drought to overcome crop failure in long dry season (EI Nino phenomenon).

\section{METHODS OF RESEARCH}

The assessment was conducted in Maduran Village, Maduran District, Lamongan Regency from August to November 2015 at MK-2. Site selection was the drought-prone, but still allowed for some water. Varieties of amphibian rice used as treatment were Inpago 5, Inpago 8, Inpago 9, Inpari 10, and Situ Patenggang; Ciherang variety was used as comparison, with a total area of 10 ha. The component of Integrated Crop Management applied was the seed quality certified as class FS derived from BB Rice Sukamandi; the planting of young seedlings < 20 HSS; $2-3$ seeds/hole; planting system of tanam jajar legowo 2:1 $(20 \mathrm{~cm} \times 12.5 \mathrm{~cm} \times 40 \mathrm{~cm}$ ); fertilization according to the Decree of Minister of Agriculture; organic fertilizer $5 \mathrm{t} / \mathrm{ha}$; intermittent watering; pest-disease control with IPM. Assessment was done using Randomized Block Design with four (4) replications. Parameters observed included growth components such as plant height, tiller number, and yield components such as panicle number, panicle length, grain contents, and empty grains per panicle, and yield. The data were analyzed in a variety of ways, and the effect of the treatment was tested using Duncan at $5 \%$ degree of confidence.

\section{RESULTS AND DISCUSSION}

Characteristics of the Assessment Area. Geographically, Maduran Village, Maduran District, lies in the south latitude and east longitude. The village is about $6 \mathrm{~m}$ above sea level. It has an area of approximately 193.5 ha, consisting of 13 ha of settlements, 156 ha of paddy fields, 16 ha of plantation, 6.5 ha of home garden, and offices, parks and others cover the rest 35 ha. Rainfall average is $2400 \mathrm{~mm} /$ year, with the most rainfall occurs in December to reach $405.04 \mathrm{~mm}$, which has been the highest rainfall during the period 2000 to 2010 [6].

Results of Assessment. The study of amphibian new varieties in MK 2 was done in cooperation with the Institute of Agricultural Technology Assessment (IATA) East Java with Indonesian Center for Rice Research (ICRR) Sukamandi. At the time of assessment, Ciherang variety was the one mostly grown by farmers, due to its high production and 
productivity, and high selling value, making it the preference of the intermediaries. Based on this, Ciherang variety was used as a comparison in this study.

The result of observation on vegetative growth at the age of 45 days after planting from each variety can be seen in Table 1 . Table 1 shows that the highest rice plant was from Situ Patenggang variety $(105.33 \mathrm{~cm})$, then Inpago $9(99 \mathrm{~cm})$, and Inpago $5(75.89 \mathrm{~cm})$. However, the height of Situ Patenggang did not produce many tillers, only 15.67 , or the lowest, while the number of tillers of other varieties was around 18 to 20. Observation of growth in the productive phase was carried out in rice plants aged 93 days after planting (DAP). The highest rice plant was produced from Inpari 10, then Ciherang, Situ Patenggang, Inpago 9, Inpago 8, and Inpago 5. The highest productive tillers were for Inpago 9 of 29 tillers, followed by Inpago 5 of 20 tillers. The number of tillers for the other varieties was relatively evenly distributed, around 12 to 17 (Table 1). From the observation of plant height in the productive phase, it was close to the description of VUB Rice [7], except Inpago 5, as the plant height was lower than its description of $132 \mathrm{~cm}$.

Table 1 - Average plant height and number of tillers of several rice varieties at 45 and 93 days after planting (Lamongan 2015)

\begin{tabular}{|c|c|c|c|c|}
\hline \multirow{2}{*}{ Variety } & \multicolumn{2}{|c|}{ Height $(\mathrm{cm})$} & \multicolumn{2}{c|}{ Tiller } \\
\cline { 2 - 5 } & $45 \mathrm{DAP}$ & $93 \mathrm{DAP}$ & $45 \mathrm{DAP}$ & $93 \mathrm{DAP}$ \\
\hline Inpago 5 & $\left.75.89 \mathrm{a}^{*}\right)$ & $91.67 \mathrm{a}$ & $20.78 \mathrm{~b}$ & $20.00 \mathrm{~b}$ \\
Inpago 8 & $85.75 \mathrm{ab}$ & $101.56 \mathrm{ab}$ & $18.75 \mathrm{ab}$ & $17.56 \mathrm{ab}$ \\
Inpago 9 & $99.00 \mathrm{c}$ & $109.89 \mathrm{~b}$ & $18.89 \mathrm{ab}$ & $29.56 \mathrm{c}$ \\
Inpari 10 & $87.72 \mathrm{~b}$ & $142.78 \mathrm{~d}$ & $19.33 \mathrm{ab}$ & $12.22 \mathrm{a}$ \\
Situ Patenggang & $105.33 \mathrm{c}$ & $123.11 \mathrm{c}$ & $15.67 \mathrm{a}$ & $12.56 \mathrm{a}$ \\
Ciherang & $86.44 \mathrm{ab}$ & $130.44 \mathrm{c}$ & $19.78 \mathrm{ab}$ & $14.89 \mathrm{ab}$ \\
\hline
\end{tabular}

*) Figures followed by the same letter in the same column show no significant difference at the 5\% Duncan multiple test range.

Table 2 - The average panicle number, panicle length, grain contents, and empty grains per panicle (Lamongan 2015)

\begin{tabular}{|c|c|c|c|c|}
\hline Variety & Panicle number & Panicle length & Grain content per panicle & Empty grain per panicle \\
\hline Inpago 5 & $8.56 \mathrm{a}$ & $25.09 \mathrm{~b}$ & $176.33 \mathrm{c}$ & $19.22 \mathrm{a}$ \\
Inpago 8 & $8.33 \mathrm{a}$ & $25.97 \mathrm{~b}$ & $120.67 \mathrm{ab}$ & $16.33 \mathrm{a}$ \\
Inpago 9 & $8.67 \mathrm{a}$ & $26.97 \mathrm{~b}$ & $181.50 \mathrm{c}$ & $31.17 \mathrm{a}$ \\
Inpari - 10 & $9.44 \mathrm{a}$ & $29.50 \mathrm{~b}$ & $115.67 \mathrm{a}$ & $142.17 \mathrm{~b}$ \\
Situ Patenggang & $10.44 \mathrm{a}$ & $25.51 \mathrm{~b}$ & $167.44 \mathrm{bc}$ & $16.67 \mathrm{a}$ \\
Ciherang & $13.44 \mathrm{~b}$ & $13.56 \mathrm{a}$ & $121.67 \mathrm{ab}$ & $171.11 \mathrm{~b}$ \\
\hline
\end{tabular}

*) Figures followed by the same letter in the same column show no significant difference at the $5 \%$ Duncan multiple test range.

Based on the observation flowering (63 days after planting), visually the varieties having flowered included Situ Patenggang (75\%) and Inpari $10(80 \%)$, while others were only 30\% (Inpago 5), $15 \%$ (Inpago 8), 15\% (Inpago 9), and 20\% (Ciherang). Observation on pests and diseases was done every week, to anticipate pest explosion. Pests found during observation were false white pests, golden snails, and rats. Overall, at the time of observation of rice cropping, the rice varieties were relatively good, although the golden snail still attacked at 45 DAP, but it was not expected to affect production because the plants were strong enough.

Farmers are commonly afraid of pest attract in the generative phase such as rats, stem borer, and blast disease. However, these did not occur because the pest and disease attacks were relatively low-rats attacked about $5 \%$, golden snail $3 \%$, and fake white lice $5 \%$ at 45 DAP. Natural enemies of predators were found at the time of observation, such as Paederus fuscifes with the most populations found in the variety of Situ Patenggang on an average of 12.67 , and 1.33 to 2.67 for other varieties. Another predator is Coccinella sp. with an average population of 1 to 2 .

The results of observation on the components of panicle number, panicle length, grain contents, and empty grains per panicle can be seen in Table 2 . The highest number of 
panicles per clump is from Ciherang variety-it was different from other varieties, yet it had the lowest panicle length. The highest grain content per panicle was shown by Inpago 9, which was not different from Inpago 5 and Situ Patenggang. The lowest empty grain per panicle was found in Inpago 8, which was not significantly different with Inpago 5, Inpago 9, and Situ Patenggang.

The results of observations on the production of Dried Unhulled Rice can be seen in Table 3. The highest rice yield was for Inpago 9 variety of $8.31 \mathrm{t} / \mathrm{ha}$. Based on discussions with farmer groups during field meeting, this variety was the most favored for its long grain, bright grain color, unlined grain, clear rice color, and compact grain. The production achieved by Inpago 9 approaches the potential yield of $8.4 \mathrm{t} /$ [7]. The production of other varieties (Inpago 5, Inpago 8, Situ Patenggang, and Inpari 10) was equivalent to Ciherang variety as the comparison (Table 3).

Table 3 - The productivity of amphibian varieties (Lamongan 2015)

\begin{tabular}{|c|c|c|}
\hline Variety & Yield (t/ha) & Weight of 1000 grains $(\mathrm{g})$ \\
\hline Inpago 5 & $7.56 \mathrm{c}$ & 28.64 \\
Inpago 8 & $5.17 \mathrm{a}$ & 32.42 \\
Inpago 9 & $8.31 \mathrm{~d}$ & 30.33 \\
Inpari - 10 & $7.22 \mathrm{c}$ & 32.77 \\
Situ Patenggang & $5.78 \mathrm{ab}$ & 30.50 \\
Ciherang & $5.92 \mathrm{~b}$ & 30.20 \\
\hline
\end{tabular}

*) Figures followed by the same letter in the same column show no significant difference at the $5 \%$ Duncan multiple test range.

\section{CONCLUSION}

Inpago 5, 8, 9, Situ Patenggang, and Inpari 10 showed positive response to plant growth (plant height and number of tillers). The high growth is also supported by the use of high organic material (5 tons/ha), because farmers usually only use organic material at 500 $\mathrm{kg} / \mathrm{ha}$. The highest Dried Unhulled Rice production was for Inpago 9 variety $(8.31 \mathrm{t} / \mathrm{ha}$ Dried Unhulled Rice). With the existence of amphibian rice varieties suitable for drought conditions, crop failure can be avoided.

\section{REFERENCES}

1. Dinas Pertanian Provinsi Jawa Timur, 2014. Program Pembanguan Pertanian Tanaman Pangan 2013. Disampaikan dalam Acara Sinkronisasi Program Pertanian, Surabaya.

2. Dinas Pertanian Provinsi Jawa Timur. 2013. Program Pembangunan Pertanian Tanaman Pangan 2013. Disampaikan dalam Acara Sinkronisasi Program Pertanian, Surabaya.

3. Dinas Pertanian Provinsi Jawa Timur, 2015. Program Pembangunan Pertanian Tanaman Pangan 2015. Disampaikan dalam Acara Sinkronisasi Program Pertanian, Surabaya.

4. Badan Penelitian dan Pengembangan Pertanian, 2014. Petunjuk Pelaksanaan Sosialisasi Katam Terpadu (Kalender Tanam Terpadu). Badan Litbang Pertanian. Jakarta.

5. UNDP, 2007. Sisi Lain Perubahan Iklim: Mengapa Indonesia harus beradaptasi untuk melindungi rakyat miskinnya. United Nation Development Programme Indonesia. UNDP Indonesia Country Office. Jakarta.

6. Anonim. 2015. Monografi Desa. Profil Desa Maduran. Kec. Maduran Lamongan.

7. Mejaya, MJ, Satoto, P. Sasmita, Y. Baliadi, A. Kuswara dan Suharna. 2014. Deskripsi Varietas Unggul Baru Padi. Balitbangtan.

(c) 2017 by the author. Licensee RJOAS, Orel, Russia. This article is an open access article distributed under the terms and conditions of the Creative Commons Attribution (CC BY) license: http://creativecommons.org/licenses/by/4.0/ 